\title{
Anti-NMDAR encephalitis in a patient with Crohn disease receiving adalimumab
}

Geoffrey P. Noble, MD, PhD, and Eric Lancaster, MD, PhD

Neurol Neuroimmunol Neuroinflamm 2018;5:e476. doi:10.1212/NXI.0000000000000476

Anti-tumor necrosis factor alpha (TNF- $\alpha$ ) therapies have been a significant advance in the treatment of autoimmune and rheumatologic diseases. Early preclinical and clinical studies of anti-TNF- $\alpha$ therapies emphasized infection and malignancy as serious adverse events associated with these agents. ${ }^{1}$ However, subsequent clinical experience has increasingly recognized a rare and seemingly paradoxical risk of autoimmunity with agents targeting the TNF- $\alpha$ pathway, most notably psoriatic eruptions, ${ }^{2}$ but also autoimmune processes associated with autoantibody production, including systemic vasculitis and lupus erythematosus. ${ }^{3,4}$ The development of neurologic diseases in association with anti-TNF- $\alpha$ therapy has been documented in case series and small prospective studies, ${ }^{5}$ with the most commonly reported associations being demyelinating diseases of the CNS and peripheral nervous systems. Here, we report a patient who developed anti-NMDA receptor (NMDAR) encephalitis while being treated with adalimumab for Crohn disease.

The patient was a 58-year-old woman diagnosed with Crohn disease at 36 years of age. She was treated with 5-aminosalicylates for many years, followed by azathioprine $100 \mathrm{mg}$ daily beginning 3 years before her presentation. Six months before presentation, adalimumab $40 \mathrm{mg}$ every other week was added, which she initially tolerated well. In the 3 weeks leading up to her presentation, the patient developed a progressive encephalopathy, beginning with headache and fatigue, followed by perceptual disturbances with disequilibrium and hyperesthesia, and then development of confusion and word finding difficulty. She was admitted to an outside hospital during this time with episodes of tachycardia for which a workup was unrevealing.

On presentation to our hospital, she was anxious and perseverative. Her general medical examination and basic laboratory testing were unremarkable. On neurologic examination, she was found to have poor attention and was unable to spell "world" backward or follow embedded commands. Her language was stuttering, and she had some anomia for lowfrequency objects. During her hospitalization, the patient continued to have intermittent episodes of dysautonomia with tachycardia and hypotension. MRI of the brain with and without contrast and routine EEG performed on hospital day 2 were unremarkable. A lumbar puncture on hospital day 4 was significant for elevated CSF protein levels (63 mg/ $\mathrm{dL}$ ) with normal cell counts and glucose. CSF testing for NMDAR antibodies was positive in the clinical laboratory of the Hospital of the University of Pennsylvania. Research studies using screening against brain sections and CSF NMDAR cell-based assays were positive following our reported methods. ${ }^{6}$ An MRI of the pelvis with and without contrast obtained before discharge showed no evidence of an ovarian teratoma or other pelvic malignancy. Adalimumab and azathioprine were discontinued, and she was treated with IV methylprednisolone $1,000 \mathrm{mg}$ daily and IV immunoglobulin $0.4 \mathrm{~g} / \mathrm{kg}$ daily for 5 days (hospital days 5 through 9) without significant clinical improvement, followed by rituximab $1,000 \mathrm{mg} \times 2$ doses starting on hospital day 11 . Her symptoms started improving

\author{
Correspondence \\ Dr. Lancaster \\ eric.lancaster@uphs.upenn.edu
}


several days after the first rituximab dose. She was discharged to a rehabilitation facility on hospital day 15 .

The patient made a full functional recovery over 3 months and returned to work as a skilled professional. A repeat MRI of the pelvis performed 1 year after her initial presentation was again negative for pelvic malignancy. Now at 2 years after her initial presentation, the patient continues to do well without clinical relapses of anti-NMDAR encephalitis or Crohn disease. She has not received any further immunomodulatory treatments for anti-NMDAR encephalitis but was recently started on vedolizumab for Crohn disease.

Anti-NMDAR encephalitis has previously been reported in 2 patients treated with the immune checkpoint inhibitors nivolumab and ipilimumab. ${ }^{7}$ Here, we have described a patient developing autoimmune encephalitis in association with anti-TNF- $\alpha$-targeted therapy. Although causality in this instance cannot be proven, the patient's age at onset, the absence of a concurrent ovarian teratoma, and temporal association argue that adalimumab may be the inciting event. The mechanism by which anti-TNF- $\alpha$ therapy might lead to autoimmune disease is unknown. In the case of anti-TNF$\alpha$-triggered psoriasis, there is speculation that a systemic cytokine imbalance, with relative overproduction of interferon alpha in the setting of TNF- $\alpha$ suppression, leads to dysregulated $\mathrm{T}_{\mathrm{H}} 1$-mediated immune responses. ${ }^{2}$ In the case of autoantibody production, which would be expected to involve a $\mathrm{T}_{\mathrm{H}}$ 2-driven response, it may be that TNF- $\alpha$ suppression in complex cytokine environments such as the intestinal mucosa creates microenvironments within which local aberrant priming and expansion of a self-reactive B-cell population may occur. Regardless, neurologists should be aware of the potential for paradoxical autoimmune phenomena to occur with novel immunotherapies and to consider these medications as potential etiologic agents in patients who develop new neurologic complaints.

\section{Author contributions}

G.P. Noble: writing of the manuscript. E. Lancaster: study concept and critical revision of the manuscript.

\section{Study funding}

No targeted funding reported.

\section{Disclosure}

G.P. Noble reports no disclosures. E. Lancaster served on the advisory board of Grifos, Amgen, and Janssen; received travel funding and speaker honoraria from Grifols; consulted for Medimmune, Merck, and Novartis; received fees for expert review of cases for the Federal Vaccine Injury Compensation Program; received research support from Grifols and NINDS; and provided medical legal consultation for Rogers Towers PA, Orlando Health, and Wilson, Elser, Moskowitz, Edelman \& Dicker LLP. Full disclosure form information provided by the authors is available with the full text of this article at Neurology.org/NN.

Received May 2, 2018. Accepted in final form May 30, 2018.

\section{References}

1. Bongartz T, Sutton AJ, Sweeting MJ, Buchan I, Matteson EL, Montori V. Anti-TNF antibody therapy in rheumatoid arthritis and the risk of serious infections and malignancies: systematic review and meta-analysis of rare harmful effects in randomized controlled trials. JAMA 2006;295:2275-2285.

2. Collamer AN, Battafarano DF. Psoriatic skin lesions induced by tumor necrosis factor antagonist therapy: clinical features and possible immunopathogenesis. Semin Arthritis Rheum 2010;40:233-240.

3. Perez-De-Lis M, Retamozo S, Flores-Chavez A, et al. Autoimmune diseases induced by biological agents: a review of 12,731 cases (BIOGEAS registry). Expert Opin Drug Saf 2017;16:1255-1271.

4. Sokumbi O, Wetter DA, Makol A, Warrington KJ. Vasculitis associated with tumor necrosis factor-alpha inhibitors. Mayo Clinic Proc 2012;87:739-745.

5. Deepak P, Stobaugh DJ, Sherid M, Sifuentes H, Ehrenpreis ED. Neurological events with tumour necrosis factor alpha inhibitors reported to the Food and Drug Administration Adverse Event Reporting System. Aliment Pharmacol Ther 2013;38:388-396.

6. McCracken L, Zhang J, Greene M, et al. Improving the antibody-based evaluation of autoimmune encephalitis. Neurol Neuroimmunol Neuroinflamm 2017;4:e404. doi: 10.1212/NXI.0000000000000404

7. Williams TJ, Benavides DR, Patrice KA, et al. Association of autoimmune encephalitis with combined immune checkpoint inhibitor treatment for metastatic cancer. JAMA Neurol 2016;73:928-933. 


\title{
Neurology \\ Neuroimmunology \& Neuroinflammation
}

\author{
Anti-NMDAR encephalitis in a patient with Crohn disease receiving adalimumab \\ Geoffrey P. Noble and Eric Lancaster \\ Neurol Neuroimmunol Neuroinflamm 2018;5; \\ DOI 10.1212/NXI.0000000000000476
}

This information is current as of July 2, 2018

\section{Updated Information \& Services \\ References \\ Subspecialty Collections}

Permissions \& Licensing

Reprints including high resolution figures, can be found at:

http://nn.neurology.org/content/5/5/e476.full.html

This article cites 7 articles, 0 of which you can access for free at: http://nn.neurology.org/content/5/5/e476.full.html\#\#ref-list-1

This article, along with others on similar topics, appears in the following collection(s):

All Clinical Neurology

http://nn.neurology.org//cgi/collection/all_clinical_neurology

Autoimmune diseases

http://nn.neurology.org//cgi/collection/autoimmune_diseases

Gastrointestinal

http://nn.neurology.org//cgi/collection/gastrointestinal

Information about reproducing this article in parts (figures,tables) or in its entirety can be found online at:

http://nn.neurology.org/misc/about.xhtml\#permissions

Information about ordering reprints can be found online:

http://nn.neurology.org/misc/addir.xhtml\#reprintsus

Neurol Neuroimmunol Neuroinflamm is an official journal of the American Academy of Neurology.

Published since April 2014, it is an open-access, online-only, continuous publication journal. Copyright

Copyright $\odot 2018$ The Author(s). Published by Wolters Kluwer Health, Inc. on behalf of the American

Academy of Neurology.. All rights reserved. Online ISSN: 2332-7812.

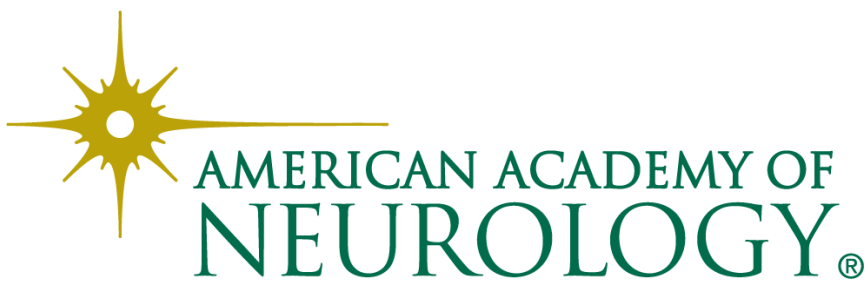

